\title{
ANALISIS ATRIBUT PRODUK PADA MANAJEMEN MUTU PROSES PRODUKSI DAGING SAPI DI RPH PT. ELDERS INDONESIA, BOGOR
}

\author{
ANALYSIS OF PRODUCT ATTRIBUTES ON THE QUALITY MANAGEMENT PROCESS OF BEEF \\ PRODUCTION IN SLAUGHTERING HOUSE OF PT. ELDERS INDONESIA, BOGOR
}

\author{
Asep Hapidin*)1, Abdul Basith**), dan Jono M. Munandar**) \\ *) PT Elders Indonesia \\ Jl. Letjen TB Simatupang Kav 1, Cilandak Timur Pasar Minggu Jakarta Selatan, Jakarta 12560 \\ ${ }^{* *}$ Departemen Manajemen, Fakultas Ekonomi dan Manajemen, Institut Pertanian Bogor \\ Jl. Agatis Kampus IPB Darmaga, Bogor 16680
}

\begin{abstract}
This study aimed to identify and analyze product attributes that affect the quality management of the beef production process in PT. Elders Indonesia, as well as to evaluate the quality management system and food safety management system, and formulate alternative improvement strategies on product attributes that are in line with consumer desires and expectations. The research method used brainstorming to identify product attributes, QFD analysis to determine the specifications of consumer needs and desires, self-assessment for the assessment of the application of SMM and SMKP, HACCP for identification of hazards in the production process, and AHP for the formulation of alternative priority improvement strategies. The results of the study showed that there were 15 attributes that the consumers considered when buying beef in PT. Elders Indonesia. Meanwhile the elements of ISO 9001: 2008 quality management in the production and HACCP food safety management system as a whole have been fulfilled and have been applied well. Based on the identification of critical control points at the process stage, there are 4 critical control points that must be considered by PT. Elders Indonesia. AHP analysis results showed that fat thickness (0.457) is the main improvement priority that must be conducted by the company.
\end{abstract}

Keywords: quality management, product attributes, beef, slaughterhouses

\begin{abstract}
Abstrak: Penelitian ini bertujuan mengidentifikasi dan menganalisis atribut-atribut produk yang berpengaruh pada manajemen mutu proses produksi daging sapi di RPH PT. Elders Indonesia, serta mengevaluasi sistem manajemen mutu dan sistem manajemen keamanan pangan, merumuskan alternatif strategi perbaikan pada atribut produk yang sesuai dengan keinginan dan harapan konsumen. Metode penelitian menggunakan brainstorming untuk identifikasi atribut produk, analisis QFD untuk menetapkan spesifikasi kebutuhan dan keinginan konsumen, self Assessment untuk penilaian penerapan SMM dan SMKP, HACCP untuk identifikasi bahaya pada proses produksi, AHP untuk perumusan alternatif strategi prioritas perbaikan. Hasil penelitian menunjukan bahwa yang menjadi pertimbangan konsumen dalam membeli daging sapi PT. Elders Indonesia sebanyak 15 atribut. Sementara itu unsur-unsur manajemen mutu ISO 9001:2008 pada bagian produksi dan sistem manajemen keamanan pangan HACCP secara keseluruhan telah dipenuhi dan telah diaplikasikan dengan baik. Berdasarkan identifikasi titik kendali kritis pada tahapan proses diperoleh empat titik kendali kritis yang harus diperhatikan oleh PT. Elders Indonesia. Hasil analisis AHP menunjukan bahwa ketebelan lemak $(0,457)$ merupakan prioritas perbaikan utama yang harus dilakukan perusahaan.
\end{abstract}

Kata kunci: atribut produk, manajemen mutu, daging sapi, rumah pemotongan hewan

\footnotetext{
${ }^{1}$ Corresponding author:

Email: hapidinasep@yahoo.com
} 


\section{PENDAHULUAN}

Dalam menghadapi liberalisasi perdagangan, Indonesia harus mempercepat peningkatan daya saing, baik dari sisi permintaan (demand) maupun dari sisi penawaran (supply). Keinginan konsumen dari sisi permintaan terhadap suatu produk semakin kompleks yang menuntut berbagai atribut atau produk yang dipersepsikan bernilai tinggi oleh konsumen (consumer's value perception). Dahulu konsumen hanya mengevaluasi produk berdasarkan atribut utama, yaitu jenis dan harga, sedangkan sekarang konsumen sudah menuntut atribut yang lebih rinci lagi seperti atribut keamanan produk (safety attributes), atribut nutrisi (nutritional attributes), atribut nilai (value attributes), atribut pengepakan (package attributes), atribut lingkungan (ecolabel attributes), dan atribut kemanusiaan (humanistic attributes) (Attahmid, 2009).

Demikian halnya perusahaan-perusahaan yang bergerak di bidang produksi pangan, apabila ingin memiliki keunggulan dalam skala global maka perusahaanperusahaan tersebut harus mampu melakukan setiap pekerjaan secara lebih baik dalam rangka menghasilkan produk pangan berkualitas tinggi dengan harga yang wajar dan bersaing. Hal ini berarti agar perusahan atau industri pangan mampu bersaing secara global diperlukan kemampuan mewujudkan produk pangan yang memiliki sifat aman (tidak membahayakan), sehat dan bermanfaat bagi konsumen.

Daging sapi merupakan sumber protein yang diminati oleh konsumen diIndonesia selain daging ayam dan daging kambing/domba. Alasan-alasan konsumen menyukai daging sapi ini antara lain karena, pertimbangan gizi, status sosial, pertimbangan kuliner, dan pengaruh budaya barat (Jonsen, 2004), disamping itu nilai kecernaan protein daging sapi tinggi mencapai 95-100\% dibandingkan kecernaan protein tanaman yang hanya 65-75\% (Aberle et al. 2001).

Saat ini produk yang dihasilkan Rumah Pemotongan Hewan (RPH) PT. Elders Indonesia adalah daging segar dingin yang sudah dikemas sedemikian rupa dan telah menerapkan sistem keamanan pangan dalam berproduksinya. Dengan diterapkannya sistem keamanan pangan, maka perusahaan memilikinilai lebih dimata konsumen bahwa produk yang dihasilkan aman untuk dikonsumsi dan terbebas dari sumber penyakit yang diakibatkan adanya agen pembawa penyakit dari daging sapi yang dihasilkan. Pengamanan daging sapi harus dilakukan dengan tujuan untuk menjamin masyarakat sebagai konsumen mendapatkan daging sapi yang aman untuk dikonsumsi (Nugroho, 2008). Selanjutnya, Yanti et al. (2008), menjelaskan bahwa usaha penyediaan daging sapi memerlukan perhatian khusus karena daging mudah dan cepat tercemar oleh pertumbuhan mikroorganisme yang berdampak pada menurunnya daya simpan dan nilai gizi yang terkandung pada daging.

Rumah Pemotongan Hewan (RPH) merupakan suatu komplek bangunan yang memiliki desain dan kontruksi khusus yang digunakan sebagai tempat pemotongan hewan. Ketentuan mengenai RPH diatur dalam Surat Keputusan Menteri Pertanian No. 555/Kpts/ TN.240/9/1986 dan ditetapkan (SNI) Standar Nasional Indonesia 01-6159-1999 tentang rumah pemotongan hewan. RPH merupakan unti pelayana masyarakat untuk memenuhi penyediaan daging sapi yang aman, sehat, utuh dan halal sebagai tempat pemotongan hewan yang benar dan tempat pemantauan (survailen) penyakit hewan dan sejenisnya (Tolistiawati et al. 2015). RPH PT. Elders Indonesia telah menerapkan sistem manajemen keamanan pangan dan telah mendapatkan sertifikat ISO 9001 dari badan sertifikasi SAI Global, sistem HACCP, sertifikat Halal dari Majelis Ulama Indonesia (MUI), Nomor Kontrol Veteriner (NKV), artinya produk yang dihasilkan perusahaan sudah melalui proses audit yang dilakukan pihak badan sertifikasi terkait.

Penelitian ini bertujuan untuk identifikasi dan analisis faktor-faktor yang berpengaruh melalui atribut produk pada daging sapi yang dihasilkan oleh perusahaan, serta mengevaluasi sistem manajemen mutu dan sistem manajemen keamanan pangan yang telah diterapkan perusahaan, merumuskan aternatif strategi prioritas perbaikan yang harus dilakukan perusahaan berdasarkan atribut produk yang sesuai harapan konsumen.

Ruang lingkup penelitian ini mencakup kajian faktorfaktor yang berpengaruh dalam manajemen mutu proses produksi sapi di Rumah Pemotongan Hewan (RPH) PT. Elders Indonesia, evaluasi penerapan Sistem Manajemen Mutu (SMM) dan penerapan Sistem Manajemen Keamanan Pangan (SMKP) di RPH PT. Elders Indonesia. Hasil analisa dari kajian yang dilakukan akan menjadi gambaran terhadap peningkatkan mutu produk daging sapi di RPH PT. Elders Indonesia melalui atribut produk yang sesuai dengan keinginan dan harapan konsumen. Strategi 
yang dihasilkan ditujukan kepada perusahaan dan rekomendasi perbaikan terhadap atribut produk diserahkan kepada pihak manajemen perusahaan.

\section{METODE PENELITIAN}

Penelitian ini menggunakan analisis deskriptif dalam bentuk studi kasus pada RPH PT. Elders Indonesia. Analisis deskriptif dilakukan dengan pengamatan langsung, wawancara dan studi literatur. Penelitian dilaksanakan pada bulan Agustus 2017-Oktober 2017 di PT. Elders Indonesia yang terletak di Jl. Agatis lingkar kampus IPB Dramaga Bogor.

Jenis dan sumber data yang digunakan dalam penelitian ini menggunakan data primer dan data sekunder. Data primer berupa hasil wawancara dan observasi menggunakan kuisioner kepada konsumen PT. Elders Indonesia, serta acuan dari pustaka dalam memperoleh data. Dilakukan wawancara secara mendalam kepada pakar yang terkait dengan proses produksi untuk menentukan tujuan yang hendak dicapai yaitu peningkatan penjualan perusahaan dengan prioritas perbaikan atribut produk yang harus dilakukan. Data sekunder diperoleh dengan melakukan penelusuran pustaka dan dokumen terkait dengan penelitian.

Responden merupakan konsumen tetap PT. Elders Indonesia sebanyak 30 orang yang memiliki pengetahuan tentang daging sapi. Konsumen merupakan laki-laki dan perempuan perwakilan dari pihak konsumen pada masing-masing divisi daging sapi. Metode sampling dalam penelitian ini adalah mengggunakan tehnik purposive sampling. Purposive sampling adalah suatu metode untuk menentukan siapa target yang akan dijadikan anggota sampel dan juga peneliti harus memiliki pengetahuan utnuk memilih responden yang benar-benar dapat memberikan informasi yang sesuai dengan masalah yang akan diteliti (Ferdian, 2012). Penetapan sumber informasi yang didapat dari responden pakar dimaksudkan untuk penentuan prioritas perbaikan pada atribut produk. Responden pakar yang ditetapkan merupakan orangorang dalam perusahaan yang memiliki pemahaman terkait proses produksi dan memiliki pengalaman serta kompetensi dibidang proses produksi daging sapi, yaitu Direktur Operasi, Manajer Produksi, Manajer QA/QC, Supervisor Produksi.
Data yang sudah diperoleh kemudian diolah agar memiliki arti untuk memecahkan masalah pada penelitian ini. Pengolahan data untuk atribut produk diidentifikasi dan dianalisis mengunakan teknik Brainstroming dan metode Quality Function Deployment (QFD) untuk memperoleh atribut produk yang harus diperbaiki. Evaluasi penerapan unsurunsur sistem keamanan produk baik ISO maupun HACCP menggunakan metode Self Assessment terkait dengan unsur-unsur sistem keamanan pangan apa saja yang telah diterapkan perusahaan. Selain itu, analisis prioritas perbaikan terkait atribut produk, faktor, aktor dan tujuan menggunakan AHP yang dianalisis dengan bantuan perangkat lunak Expert Choice 2000.

\section{Metode Brainstorming}

Metode sumbang saran (brainstorming) adalah kombinasi dari tanya jawab dan diskusi, kemudian menghimpun pendapat yang telah disampaikan dari peserta yang terlibat (Romadhoni, 2014). Osborn dalam Rofieq (2012) menjelaskan bahwa brainstorming memiliki arti sumbang pendapat dengan menyampaikan ide-ide yang tidak terbatas yang dikaitkan dengan suatu masalah yang dihadapi dalam sebuah pertemuan yang direncanakan. Brainstroming pada umumnya ide-ide yang dihasilkan dalam sebuah kelompok diskusi.

\section{Metode Quality Function Deployment (QFD)}

Pada tahap ini, perusahaan mengevaluasi hal-hal yang menjadi kebutuhan dan harapan konsumen, sehingga strategi apa yang akan diambil oleh perusahaan untuk meningkatkan kepuasan pada pelanggannya (Irene dan Ruswandi, 2013). Langkah-langkah pada penyusunan matriks House of Quality (HOQ), yaitu Gasperz dalam Attahmid (2009): (1) Identifikasi keinginan konsumen, merupakan tahap untuk mendefinisikan keinginan konsumen terkait atribut produk. (2) Evaluasi atribut Produk, Pembobotan yang telah ditetapkan pada kuisioner dibuat rentang antara 1 sampai 5 skala (likert).

\section{Metode Self Assessment}

Self assessment merupakan komponen penting dalam pengembangan diri. Self assessment pada satu komponen kompetensi dengan baik, belum tentu mampu melakukan dengan mengintegrasikan seluruh komponen kompetensi suatu organisasi (Novitasari dan Djuniadi, 2015). Self assessment adalah metode 
penilaian dengan melibatkan orang atau organisasi terkait hal-hal yang telah dicapai (Trisno, 2014). Langkah-langkah dalam penilaian self assessment, yaitu a) Aspek-aspek untuk menentukan penilaian kompetensi dan kemampuan; b) Penilaian kriteria yang akan digunakan yang telah ditentukan; c) Merancang sebuah format penilaian yang dapat berupa penilaian, daftar tanda ceklis ataupun skala skoring.

\section{Metode Analytical Hierarchy Process (AHP)}

Tahap-tahap pada metode AHP dapat dijelaskan seperti penjelasan dibawah ini (Saaty, 2008): 1) Mengidentifikasi masalah dan penentuan solusi sesuai keinginan; 2) Menyusun struktur hierarki seperti tujuan, subtujuan, dan alternatif; 3) Menyususn matrik perbandingan mengeni gambaran kontribusi relatif dan pengaruhnya terhadap elemn pada tiap-tiap tujuan dan kriteria; 4) Merumuskan dan menghitung perbandingan berpasangan dengan menggunakan rumus $\mathrm{n} \times[(\mathrm{n}-1) / 2]$ dimana $\mathrm{n}$ adalah banyaknya unsur yang dibandingkan; 5) Melakukan perhitungan untuk memperoleh nilai eign serta menguji konsistensi, apabila tidak konsisten maka harus diulang; 6) Melakukan langkah ke-3, 4 dan 5 keseluruhan pada level hierarki; 7) Melakukan perhitungan pada eign vektor dari tiap-taip matriks perbandingan berpasangan. Bobot nilai pada tiap unsur dinamakan eign vektor. Pada tahap ini ditujukan untuk mensintesis judgment dalam menentukan unsur-unsur pada lever hierarki yang paling bawah sampai dengan mencapai tujuan; 8) Mencek ulang konsisten tidaknya hierarki. Apabila ditemukan nilai dengan bobot lebih dari $10 \%$ maka penilaian harus diperbaiki. Kerangka pemikiran penelitian selengkapnya pada Gambar 1 .

\section{HASIL}

\section{Harapan Konsumen (Customer Needs and Benefits)}

Atribut yang dijadikan input dalam rumah mutu daging sapi pada kondisi aktual, yaitu rasio lemak, rasa, warna, marbling, jiuci, aroma, kehalalan, kesegaran, harga, tekstur, ketersediaan dipasar (Arkeman et al. 2015). Hasil wawancara dengan konsumen dengan menggunakan tehnik brainstorming, diperoleh 15 atribut mutu produk daging sapi yang menjadi prioritas konsumen dalam memilih produk daging sapi. Atribut mutu produk meliputi: ketebalan lemak, warna daging, warna lemak, perubahan warna daging, freezburn permukaan daging, kebersihan daging, keempukan daging, marbling/lemak dalam daging, tekstur daging, volume daging, desain kemasan daging, daya tahan umur simpan, flavor/rasa, merk kemasan daging, dan keseluruhan penampilan daging.

\section{Tanggapan Atas Kebutuhan Konsumen (Relationship)}

Hasil analisis relationship tingkat kepuasan atas kebutuhan konsumen terhadap atribut mutu produk daging sapi PT. Elders Indonesia, menunjukan bahwa tingkat kepuasan atas kebutuhan konsumen terhadap atribut mutu produk daging sapi PT. Elders Indonesia, dapat diketahui rata-rata atribut mutu produk daging sapi perusahaan memuaskan bagi konsumen dengan nilai 4, hal ini menunjukkan bahwa mutu produk daging sapi PT. Elders Indonesia diterima dengan baik oleh konsumen. Hasil analisis relationship tingkat kepuasan atas kebutuhan konsumen terhadap atribut mutu produk daging sapi PT. Elders Indonesia disajikan pada Tabel 2.

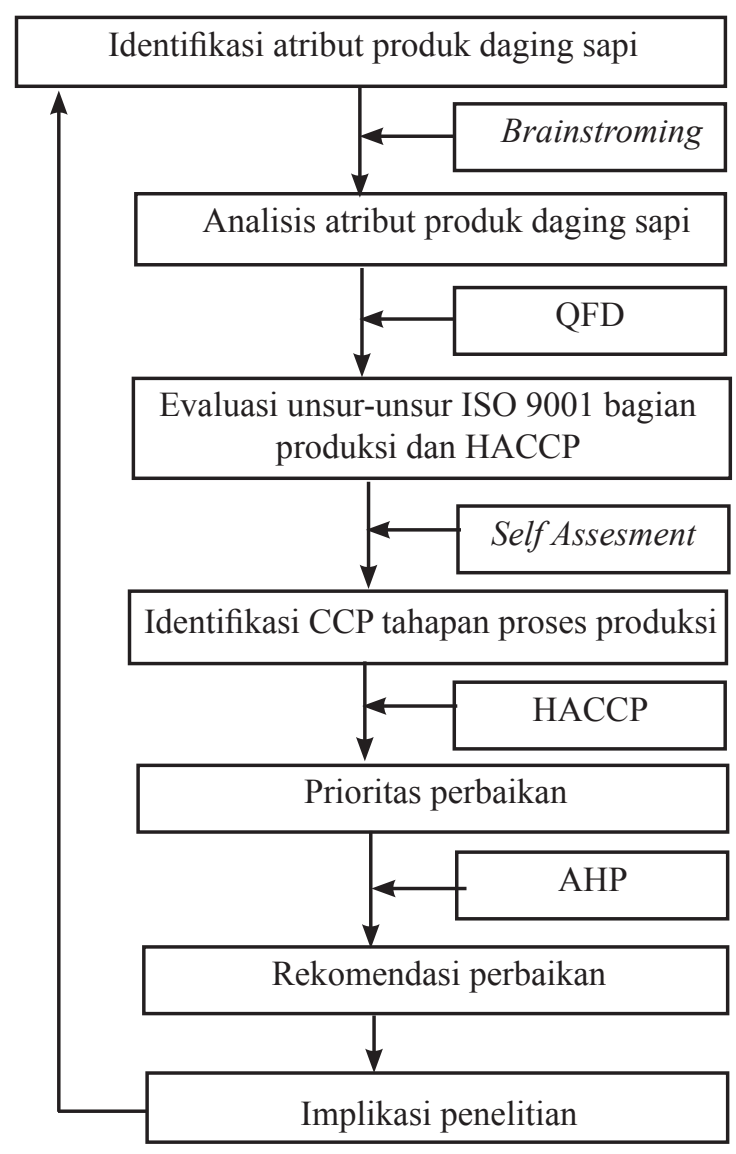

Gambar 1. Kerangka pemikiran penelitian 


\section{Riset Pasar dan Rencana Strategik (Planning Matrix)}

Tahap ini merupakan tahap untuk mengkaji keinginan pasar berdasarkan penilaian konsumen mengenai sasaran perusahaan untuk memperbaiki dan meningkatkan mutu produkyang dihasilkan perusahaan. Atribut mutu yang mempunyai rasio perbaikan 1,00 atau yang telah memenuhi harapan konsumen antara lain adalah warna daging, volume daging, desain kemasan, flavor/rasa, daya tahan umur simpan, merek kemasan, keseluruhan, sedangkan atribut mutu yang mempunyai rasio perbaikan lebih besar dari 1,00 atau yang belum memenuhi harapan konsumen antara lain adalah ketebalan lemak, warna lemak, perubahan warna daging, freezburn, marbling (serat lemak dalam daging).

Hasil analisis perbandingan menunjukan atributatribut produk menurut konsumen dalam memilih produk daging sapi, diketahui bahwa ketebalan lemak (13,95\%), warna lemak $(12,09 \%)$, perubahan warna daging $(11,16 \%)$, freezburn permukaan daging
(12,79\%), marbling $(7,44 \%)$ merupakan atribut-atribut produk yang harus diperbaiki bagi PT. Elders Indonesia. Hasil analisis riset pasar, sasaran dan persentase bobot (Planning Matrix) atribut mutu produk daging sapi harus dicapai oleh PT. Elders Indonesia disajikan pada pada Tabel 3.

\section{Tanggapan Atas Karakteristik Proses (Technical Matrics Response)}

Tahap ini merupakan tahap untuk menentukan jenis aktivitas proses yang terkait dengan spesifikasi dan harapan konsumen. Penentuan aktivitas proses dilakukan dengan teknik brainstorming dengan melakukan pengisian kuisioner dan studi literatur. Nilai 10 menunjukkan hubungan kuat antara atribut dengan karakteristik proses produksi, dimana proses tersebut berpengaruh kuat terhadap peningkatan atau penurunan nilai atribut produk. Nilai 5 menunjukkan hubungan sedang, nilai 1 menunjukkan hubungan lemah dan nilai 0 menunjukkan tidak adanya hubungan antara proses tersebut dengan peningkatan dan penurunan nilai atribut (Saaty, 2008).

Tabel 2. Analisis relationship tingkat kepuasan

\begin{tabular}{lccccccccc}
\hline Atribut mutu daging sapi & STP & TP & CP & P & SP & $\begin{array}{c}\text { Jumlah } \\
\text { Responden }\end{array}$ & $\begin{array}{c}\text { Total } \\
\text { Nilai }\end{array}$ & $\begin{array}{c}\text { Indeks } \\
\text { Kingkat } \\
\text { Kepuasan }\end{array}$ \\
\hline Ketebalan lemak & 0 & 14 & 11 & 5 & 0 & 30 & 81 & 16,2 & 3 \\
Warna daging & 0 & 0 & 5 & 16 & 9 & 30 & 124 & 24,8 & 4 \\
Warna lemak & 0 & 0 & 25 & 5 & 0 & 30 & 95 & 19 & 3 \\
Perubahan warna daging & 0 & 0 & 26 & 3 & 1 & 30 & 95 & 19 & 3 \\
Freezburn permukaan daging & 0 & 0 & 25 & 5 & 0 & 30 & 95 & 19 & 3 \\
Kebersihan daging & 0 & 0 & 1 & 11 & 18 & 30 & 137 & 27,4 & 5 \\
Keempukan daging & 0 & 1 & 0 & 27 & 2 & 30 & 120 & 24 & 4 \\
Marbling/lemak dalam daging & 0 & 8 & 19 & 3 & 0 & 30 & 85 & 17 & 3 \\
Tekstur daging & 0 & 0 & 3 & 25 & 2 & 30 & 119 & 23,8 & 4 \\
Volume daging & 0 & 1 & 8 & 20 & 1 & 30 & 111 & 22,2 & 4 \\
Daya tahan umur simpan & 0 & 0 & 1 & 15 & 14 & 30 & 133 & 26,6 & 4 \\
Desain kemasan daging & 0 & 0 & 1 & 13 & 16 & 30 & 135 & 27 & 5 \\
Merk kemasan daging & 0 & 0 & 3 & 24 & 3 & 30 & 120 & 24 & 4 \\
Flavour/rasa & 0 & 0 & 14 & 14 & 2 & 30 & 108 & 21,6 & 4 \\
Keseluruhan penampilan daging & 0 & 0 & 1 & 23 & 6 & 30 & 125 & 25 & 4 \\
\hline
\end{tabular}


Tabel 3. Planning matriks

\begin{tabular}{|c|c|c|c|c|c|c|}
\hline Atribut Mutu Daging Sapi & $\begin{array}{l}\text { Target } \\
\text { Nilai }\end{array}$ & $\begin{array}{c}\text { Skor } \\
\text { Evaluasi } \\
\end{array}$ & $\begin{array}{c}\text { Tingkat } \\
\text { Kepentingan }\end{array}$ & $\begin{array}{c}\text { Rasio } \\
\text { Perbaikan } \\
\end{array}$ & $\begin{array}{c}\text { Rasio Perbaikan } \\
\text { Terbobot }\end{array}$ & $\begin{array}{c}\text { Rasio Perbaikan } \\
\text { Terbobot }(\%)\end{array}$ \\
\hline Ketebalan lemak & 4 & 3 & 15 & 1,33 & 20,00 & 13,95 \\
\hline Warna daging & 4 & 4 & 14 & 1,00 & 14 & 9,77 \\
\hline Warna lemak & 4 & 3 & 13 & 1,33 & 17,33 & 12,09 \\
\hline Perubahan warna daging & 4 & 3 & 12 & 1,33 & 16,00 & 11,16 \\
\hline Freezburn permukaan daging & 5 & 3 & 11 & 1,67 & 18,33 & 12,79 \\
\hline Kebersihan daging & 5 & 5 & 10 & 1,00 & 10 & 6,98 \\
\hline Keempukan daging & 4 & 4 & 9 & 1,00 & 9 & 6,28 \\
\hline Marbling/lemak dalam daging & 4 & 3 & 8 & 1,33 & 10,67 & 7,44 \\
\hline Tekstur daging & 4 & 4 & 7 & 1,00 & 7 & 4,88 \\
\hline Volume daging & 4 & 4 & 6 & 1,00 & 6 & 4,19 \\
\hline Daya tahan umur simpan & 4 & 4 & 5 & 1,00 & 5 & 3,49 \\
\hline Desain kemasan daging & 5 & 5 & 4 & 1,00 & 4 & 2,79 \\
\hline Merk kemasan daging & 4 & 4 & 3 & 1,00 & 3 & 2,09 \\
\hline Flavour/rasa & 4 & 4 & 2 & 1,00 & 2 & 1,40 \\
\hline Keseluruhan penampilan daging & 4 & 4 & 1 & 1,00 & 1 & 0,70 \\
\hline Total & & & & 17,00 & 143,33 & 100 \\
\hline
\end{tabular}

Hasil analisis tanggapan atas karakteristik proses produksi daging sapi PT. Elders Indonesia (Technical Matrix Response), diperoleh bobot tertinggi dari keseluruhan atribut mutu produk daging sapi PT. Elders Indonesia yang berpengaruh kuat terhadap karakteristik proses produksi yang diinginkan konsumen adalah keseluruhan penampilan daging dengan bobot 157 , sedangkan bobot terendah 1 dan 8 dari keseluruhan atribut mutu produk daging sapi PT. Elders Indonesia yang berpengaruh lemah terhadap karakteristik proses produksi yang diinginkan konsumen adalah ketebalan lemak dan marbling (lemak dalam daging). Sementara itu hasil analisis tanggapan atas karakteristik proses produksi daging sapi PT. Elders Indonesia (Technical Matrix Response), diperoleh karakteristik proses produksi yang terkait dengan spesifikasi dan harapan konsumen yang menempati ranking pertama adalah penyimpanan produk dichiler karton dengan bobot nilai kepentingan 630 dan nilai relatif 0,109. Di lain pihak, karakteristik proses produksi yang terkait dengan spesifikasi dan harapan konsumen yang menempati ranking terakhir adalah penggantungan sapi dan pemotongan kepala dan kaki dengan bobot nilai kepentingan 1 dan nilai relatif 0 .

\section{Matriks Rumah Mutu}

Proses QFD dilaksanakan dengan menyusun sebuah matriks yang disebut rumah mutu atau The House of Quality (HOQ). Matriks ini menjelaskan apa saja yang menjadi harapan konsumen dan bagaimana memenuhinya. Matriks rumah mutu terdiri dari enam bagian yaitu sebagai berikut (Gaspersz, 2001): (1) Kebutuhan konsumen, berisi daftar semua kebutuhan dan harapan konsumen yang umumnya ditentukan dengan riset pasar secara kualitatif, (2) Matriks perencanaan, berisi tingkat kepuasan konsumen terhadap perusahaan dan pesaingnya, target perusahaan untuk memenuhi kebutuhan konsumen serta perbandingan kemampuan perusahaan dan pesaing dalam memenuhi kebutuhan konsumen, (3) Tanggapan teknis, merupakan aspek atau kegiatan teknis proses yang berhubungan dengan produk, (4) Hubungan keterkaitan, berisi pertimbangan tim tentang hubungan yang kuat atau lemah antara kebutuhan dan harapan konsumen, (5) Hubungan teknis, berisi penilaian mengenai penerapan antar hubungan elemen-elemen dalam tanggapan teknis dengan kebutuhan konsumen, (6) Matriks teknis, berisi informasi tentang prioritas tanggapan teknis berdasarkan kebutuhan dan harapan konsumen, perbandingan performansi teknis perusahan dengan tingkat kepentingan performansi teknis. 
Proses penilaian analisis QFD adalah menyusun satu atau lebih matriks yang disebut dengan rumah mutu (The House of Quality). Matriks tersebut menjelaskan hal-hal yang menjadi kebutuhan, keinginan konsumen, dan cara untuk memenuhinya. Rumah mutu dapat menggambarkan hubungan antara keinginan konsumen dengan aktivitas perusahaan serta mengevaluasi kemampuan perusahaan (Gasperzs, 2001). Analisa yang dilakukan terhadap rumah mutu maka diperoleh tiga hal yang harus dilakukan oleh perusahaan, yaitu memperbaiki, mempertahankan, dan meningkatkan mutu produk daging sapi. Hasil analisis QFD yang diaplikasikan ke dalam Matriks Rumah Mutu, diketahui bahwa beberapa atribut mutu yang perlu mendapat perbaikan oleh perusahaan adalah ketebalan lemak $(13,95 \%)$, warna lemak $(12,09 \%)$, perubahan warna daging (11,16\%), freezburn permukaan daging $(12,79 \%)$, marbling $(7,44 \%)$. Matriks rumah mutu selengkapnya pada Gambar 2.

\section{Penilaian Sistem Manajemen Mutu (SMM) ISO 9001:2008}

Unsur-unsur yang terkait dengan bidang produksi adalah pengendalian produksi dan penyediaan jasa, identifikasi mampu telusur, pemeliharaan produk, pengukuran dan pemantauan produk, serta pengendalian produk yang tidak sesuai. Hasil penilaian penerapan unsur-unsur ISO 9001:2008 bidang produksi PT. Elders Indonesia disajikan pada Tabel 4. Hasil penilaian penerapan unsur-unsur ISO 9001:2008 pada bagian produksi, Tabel 4 menunjukan bahwa PT. Elders Indonesia telah memenuhi empat dari lima unsur-unsur ISO yang telah diterapkan.

\section{Penilaian Sistem Manajemen Keamanan Pangan (SMKP) HACCP}

Menurut Daulay (2015) HACCP memiliki tujuan dan target yaitu untuk meminimalisir kemungkinan adanya kontaminasi mikroba patogen dan meminimalisir potensi mikroba tersebut untuk menghambat pertumbuhan dan perkembangannya. Oleh sebab itu tiap-tiap produk dan cara pengolahannya dalam idustri pangan harus sesuai dengan rencana HACCP. Sesuai dengan prinsip perusahaan, yaitu untuk menghasilkan produk yang ASUH (Aman, Sehat, Utuh, dan Halal). Aman artinya produk terbebas dari kontaminan, Sehat artinya produk memiliki gizi yang baik untuk tubuh, Utuh artinya produk yang dihasilkan tidak tercampur dengan bagian lain dari produk utama, Halal artinya proses penyembelihan dilakukan berdasarkan syariat islam. Hasil evaluasi penerapan sistem manajemen keamanan pangan HACCP PT. Elders Indonesia disajikan pada Tabel 5.

Penilaian penerapan SMKP berdasarkan sistem HACCP menunjukkan bahwa PT. Elders Indonesia telah memenuhi keseluruhan dari unsur-unsur SMKP yang telah diterapkan diperusahaan. Hal ini menunjukan bahwa dengan diterapkannya SMM dan SMKP pada produk daging sapi PT. Elders Indonesia aman untuk dikonsumsi.

\section{Hazard Analysis Critical Control Point (HACCP)}

ProsedurHACCPbertujuanmengevaluasikemungkinan bahaya yang mungkin timbul dalam suatu produksi, penetapan CCP dilakukan pada seluruh tahapan produksi. Menurut Daulay (2015) Titik kendali kritis (CCP) merupakan suatu titik dilokasi pada setiaptahapan proses produksi atau prosedur, apabila tidak terkendali dengan baik, maka kemungkinan akan menimbulkan ketidakamanan pada produk. Hasil identifikasi pada proses produksi daging sapi, ditemukan beberapa tahapan yang termasuk titik kendali kritis (CCP)(Tabel $6)$.

\section{Analytical Hierarchy Process (AHP)}

Hasil analisis sebelumnya dengan menggunakan Quality Function Deployment (QFD) diperoleh beberapa atribut yang harus diperbaiki oleh PT. Elders Indonesia yaitu, ketebalan lemak, warna lemak, freezburn permukaan daging, perubahan warna daging, dan marbling (lemak dalam daging). Oleh karena itu, atribut produk tersebut akan dimasukan kedalam struktur hierarki yang nantinya akan menjadi prioritas perbaikan utama untuk diperbaiki perusahaan.

Faktor utama yang perlu mendapatkan perhatian khusus untuk ditingkatkan adalah faktor produksi dengan bobot 0,428 karena produksi merupakan kegiatan dalam perusahaan dalam menciptakan dan memberi nilai guna terhadap produk dengan menggunakan sumber daya yang ada meliputi bahan baku, tenaga kerja, modal, mesin dan peralatan. Sehingga produk yang dihasilkan sesuai dengan tujuan perusahaan yang pada akhirnya akan memberikan kepuasan kepada konsumen. 


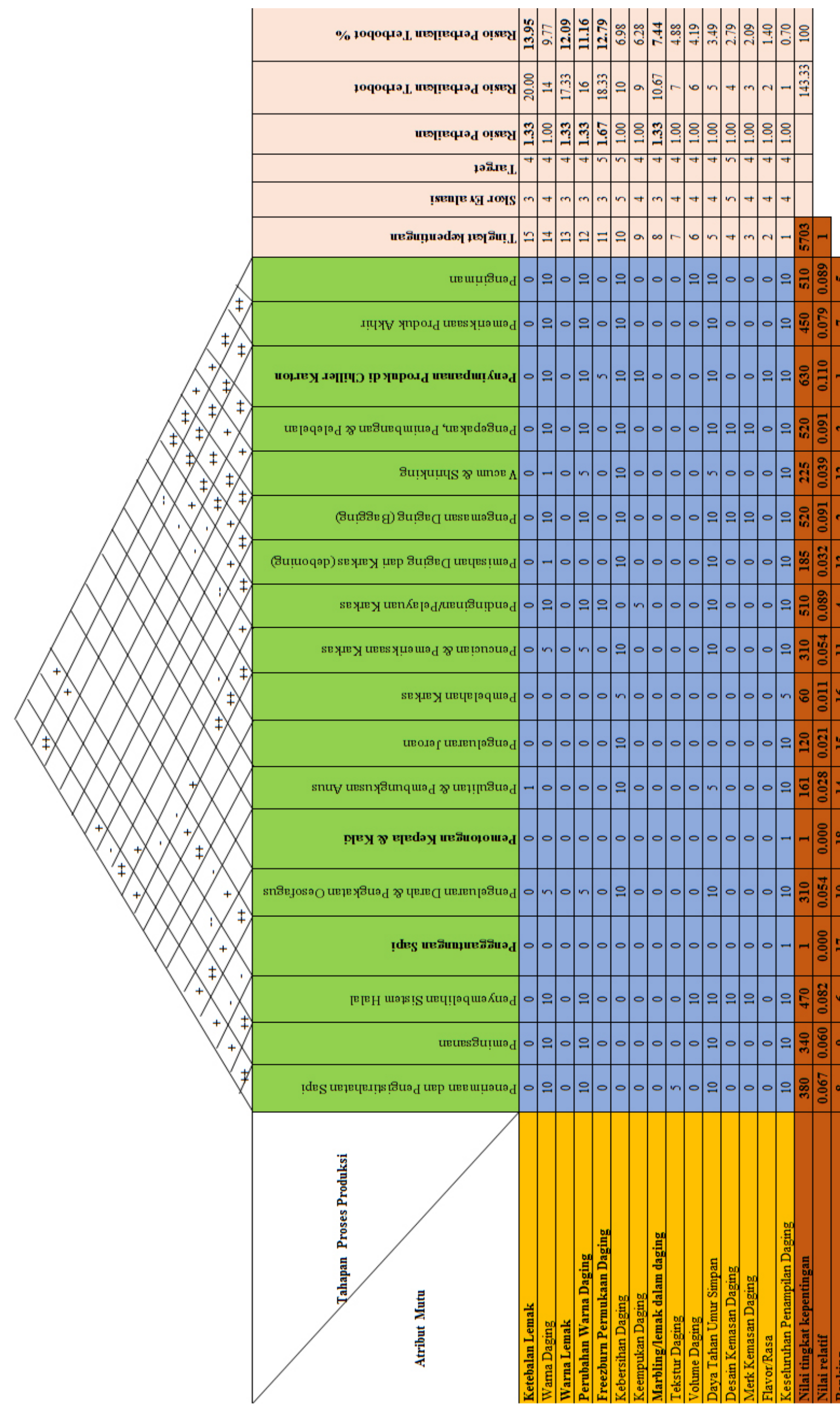


Tabel 4. Penilaian penerapan unsur-unsur ISO 9001:2008 bagian produksi

\begin{tabular}{lc}
\hline Unsur-unsur ISO & Penerapan di PT. Elders Indonesia \\
\hline 7.5.1. Pengendalian produksi dan penyediaan jasa & $\times$ \\
7.5.3. Identifikasi mampu telusur & $\sqrt{ }$ \\
7.5.5. Pemeliharaan produk & $\sqrt{ }$ \\
8.2.4. Pengukuran dan pemantauan produk & $\sqrt{ }$ \\
8.3. Pengendalian produk yang tidak sesuai & $\sqrt{ }$ \\
\hline
\end{tabular}

Tabel 5. Penilaian penerapan SMKP HACCP

\begin{tabular}{lc}
\hline Unsur-unsur ISO & Penerapan di PT. Elders Indonesia \\
\hline 1. Kebijakan mutu & $\sqrt{ }$ \\
2. Organisasi & $\sqrt{ }$ \\
2.1. Tim HACCP & $\sqrt{ }$ \\
2.2. Struktur organisasi & $\sqrt{ }$ \\
2.3. Bidang kegiatan & $\sqrt{ }$ \\
2.4. Personil dan pelatihan & $\sqrt{ }$ \\
3. Deskripsi produk & \\
4. Persyaratan dasar & $\sqrt{ }$ \\
4.1. GMP & $\sqrt{ }$ \\
4.2. SSOP & $\sqrt{ }$ \\
5. Bagan alir produksi & \\
6. Prinsip HACCP & \\
6.1. Analisa bahaya & $\sqrt{ }$ \\
6.2. Penetapan CCP & $\sqrt{ }$ \\
6.3. Penetapan batas kritis (metode \& penerapannya) & $\sqrt{ }$ \\
6.4. Pemantauan CCP atau monitoring & $\sqrt{ }$ \\
6.5. Tindakan koreksi terhadap penyimpangan & $\sqrt{ }$ \\
6.6. Catatan dan dokumentasi & $\sqrt{ }$ \\
6.7. Penetapan verifikasi & $\sqrt{ }$ \\
7. Prosedur verifikasi & $\sqrt{ }$ \\
8. Penetapan dokumentasi dan pemeliharaan pencatatan & Prosedur penanganan konsumen \\
10. Prosedur Recall & $\sqrt{ }$ \\
11. Revisi amandemen dokumen & $\sqrt{ }$ \\
\hline
\end{tabular}

Tabel 6. Titik kendali kritis (CCP) pada tahapan proses produksi PT. Elders Indonesia

\begin{tabular}{|c|c|c|}
\hline Titik kendali kritis (CCP) & Jenis bahaya & Faktor kritis \\
\hline Tahap penerimaan sapi & Biologi dan kimia & $\begin{array}{l}\text { Cemaran mikroorganisme, penyakit } \\
\text { sapi dan residu antibiotik }\end{array}$ \\
\hline $\begin{array}{l}\text { Tahap penyembelihan, penuntasan darah dan pengikatan } \\
\text { aesofagus }\end{array}$ & Biologi & Penuntasan darah \\
\hline Tahap pengeluaran jeroan/offal & Biologi & Isi jeroan \\
\hline Penyimpanan karkas diruang berpendingin (chiller) & Biologi & Suhu ruang \\
\hline
\end{tabular}


Direktur operasi merupakan aktor yang paling berpengaruh dengan bobot 0.412 . Hal ini dikarenakan Direktur operasi bertanggung jawab pada semua aktivitas operasional perusahaan yang dibawahinya meliputi, perencanaan, membuat standar perusahaan mengenai semua proses operasi, membuat strategi dalam pemenuhan target, mengawasi dan menentukan semua kebutuhan dalam proses operasi, pengambilan keputusan, pengembangankualitas produk, bertanggung jawab terhadap kualitas hasil produksi. Tujuan merupakan sasaran untuk mencapai keberhasilan dari suatu aktivitas agar sesuai dengan yang diharapkan, tujuan tersebut adalah meningkatkan keuntungan $(0,397)$. Strategi yang paling tepat untuk dijadikan proritas perbaikan pada atribut produk dengan bobot sebesar $(0,457)$, yaitu ketebalan lemak sebagai prioritas utama.

\section{Implikasi Manajerial}

Untuk mempertahankan kualitas produk yang dihasilkan perlu adanya pengawasan (controling) yang ketat dan konsisten oleh bagian Quality Control (QC), sehingga produk yang dihasilkan akan terjaga kualitasnya. Hal ini sesuai dengan pendapat Munandar et al. (2014) bahwa pengendalian merupakan kegiatan yang dilakukan dengan tujuan agar kegiatan tersebut sesuai dengan yang telah direncanakan serta memberikan tindakan koreksi pada setiap penyimpangan yang terjadi sehingga sasaran organisasi dapat tercapai. Hasil penelitian yang telah dilakukan, terdapat dua prioritas untuk diperbaiki perusahaan. Prioritas utama adalah ketebalan lemak dan perubahan warna daging sebagai pilihan kedua seperti penjelasan berikut:

\section{Memperbaiki ketebalan lemak}

Produk PT. Elders berupa daging sapi yang memiliki bermacam item yang sesuai dengan spesifikasinya masing-masing, kondisi produk yang dirasa kurang memuaskan bagi konsumen adalah lemak yang terlalu tebal pada permukaan daging sehingga membuat konsumen menyarankan PT. Elders Indonesia melakukan perbaikan untuk meghilangkan lemak yang terlalu tebal/lebih ditipiskan agar lebih menarik banyak konsumen.
Perubahan warna daging

Rekomendasi selanjutnya adalah perusahaan harus melakukan bagaimana caranya agar pada saat produk daging didistribusikan kondisi kendaraan pengangkut berpendingin suhu ruang harus stabil, sehingga pada saat mencapai tempat tujuan produk daging sapi tidak mengalami perubahan warna dan terlihat segar seperti pada saat awal dikeluarkan dari gudang pendingin milik perusahaan sebelum didistribusikan.

\section{KESIMPULAN DAN SARAN}

\section{Kesimpulan}

Hasil penelitian yang dilakukan, hasil analisis prioritas pemilihan atribut produk yang menjadi pertimbangan konsumen dalam memilih produk daging sapi PT. Elders Indonesia, yaitu keseluruhan penampilan daging; merek kemasan daging; flavour/rasa; daya tahan umur simpan; desain kemasan; volume daging; tekstur daging; marbling/lemak dalam daging; keempukan daging; kebersihan daging; freezburn permukan daging; perubahan warn daging; warn lemak; warna daging; ketebalan lemak. Pada tahapan proses produksi diperoleh 4 titik kendali kritis (CCP), yaitu (1) tahap penerimaan sapi, (2) tahap penyembelihan, penuntasan darah dan pengikatan aesofagus, (3) pengeluaran jeroan/offal, (4) penyimpanan karkas (chiller carcass).

Penilaian penerapan sistem manajemen mutu (ISO 9001:2008) dan sistem manajemen keamanan pangan (HACCP) berdasarkan analisis Self Assessment menunjukkan bahwa PT. Elders Indonesia telah memenuhi sebagian besar dari keseluruhan unsurunsur ISO 9001 yang telah diterapkan diperusahaan. Sementara itu, rekomendasi prioritas perbaikan pada atribut produk berdasarkan keinginan dan harapan konsumen terdapat pada atribut ketebalan lemak dengan bobot nilai 0,457 sebagai prioritas perbaikan utama.

\section{Saran}

Diperlukan keterlibatan Direktur Operasi sebagai pemegang kebijakan di perusahaan dalam melaksanakan rekomendasi perbaikan terkait dengan atribut-atribut produk daging sapi khususnya pada divisi QA/QC dan produksi. Dengan demikian, menciptakan keunggulan daya saing mutu dalam industri pemotongan sapi serta tercapainya tujuan perusahaan. 


\section{DAFTAR PUSTAKA}

Aberle ED, Forrest JC, Gerrard DE, dan Mills EW. 2001. Principles of Meat Science. 4th edition. Kendal:Hunt Publishing Company.

Arkeman Y, Sabrina N, Syarief R. 2015. Strategi peningkatan rantai nilai agroindustri daging sapi. Jurnal Aplikasi Manajemen (JAM) 13(4):682687.

Attahmid NFU. 2009. Strategi manajemen mutu proses produksi karkas ayam pedaging di rumah potong ayam (RPA) PT. Sierad Produce Tbk Parung Bogor [Tesis]. Bogor: Sekolah Program Pascasarjana, Institut Pertanian Bogor.

Daulay SS. 2015. Hazard Analysis Critical Control Point (HACCP) dan Implementasinya Dalam Industri Pangan. Jakarta:Widya Madya Pusdiklat Industri.

Ferdian F. 2012. Analisis permintaan ikan lele dumbo konsumsi di kecamatan Losarang, Kabupaten Indramayu. Jurnal Perikanan dan Kelautan 3(4):93-98.

Irene Y, Ruswandi B. 2013. Analisis peningkatan kualitas pelayanan dengan Quality Function Deployment (QFD) pada Laboratorium Matematika Pusat Laboratorium Terpadu. Jurnal Matematika Integratif 9(2):147-160. https://doi. org/10.24198/jmi.v9.n2.10191.147-160.

Jonsen GD. 2004. Prosfek dan preferensi masyarakat terhadap konsumsi daging sapi olahan di Indonesia. Seminar FWGD food conference. Jakarta, 6-7 Oktober 2004.

Munandar MJ, Kartika L, Permanasari Y, Indrawan DR, Andianto SM, Siregar E. 2014. Pengantar Manajemen. Komprehensif Pengelolaan Organisasi. Cetakan ke-1. Bogor: PT. Penerbit IPB Press.
Novitasari A, Djunaidi. 2015. Hubungan selfassessment dengan kompetensiklinik mahasiswa kedokteran. Jurnal Unemus1(2):127-134.

Nugroho WS. 2008. Jaminan keamanan daging sapi di Indonesia. Workshop on Helmithologi. http:// weesnugroho.staff.ugm.ac.id/wp-content/ jaminan-keamanan-daging-sapi-di-indonesia. pdf. [15 Maret 2017].

Rofieq M. 2012. Perancangan almari pakaian bayi serbaguna melalui Brainstroming dengan ibu rumah tangga. Jurnal Tehnik Industri 13(1):101107. https://doi.org/10.22219/JTIUMM.Vol13. No1.101-107.

Romadhoni S. 2014. Efektivitas penerapan metode Brainstorming terhadap peningkatan minat dan prestasi belajar ekonomi siswa kelas XI SMK YPKK 3 Sleman [skripsi]. Yogyakarta: Universitas Negri Yogyakarta.

Saaty TL. 2008. Pengambilan Keputusan Bagi Para Pemimpin (Proses Hierarki Analitik untuk Pengmbilan Keputusan dalam Situasi yang Kompleks). Edisi Bahasa Indonesia. Cetakan ke-4. Jakarta: IPMM dan PT. Pustaka Binaman Pressindo.

Tolistiowati I, Widjaja J, Isnawati R, Lobo LT. 2015. Gambaran rumah potong hewan/tempat pemotongan hewan di kabupaten Sigi, Sulawesi Tengah. Jurnal Vector Penyakit 9(2):45-52.

Trisno TRW. 2014. Metode Self Assessment sebagai metode alternatif dalam melakukan evaluasi belajar mahasiswa. Jurnal Ilmiah Bahasa dan Sastra 1(1):10-19.

Yanti H, Hidyati, Elfawati. 2008. Kualitas daging sapi dengan kemasan plastic PE (Polyethilen) dan pastik PP (Polypropilen) dipasar Arengka kota Pekanbaru. Jurnal Peternakan 5(1):22-27. 